\title{
The Changing Political Landscape for Elected Prosecutors
}

\author{
David Alan Sklansky*
}

\section{INTRODUCTION}

District attorney races are going off script. For years the only serious question about selecting local prosecutors by popular vote, a practice unique to the United States, ${ }^{1}$ was whether it was pernicious or merely a charade. One view was that running for reelection turned prosecutors into politicians, and that politics demanded that prosecutors appear tough and unforgiving. ${ }^{2}$ Plus, elections forced prosecutors to stay cozy with the police: they needed the endorsements of law enforcement officials and police unions if they wanted to retain their jobs, and all the more so if they had larger political ambitions. ${ }^{3}$ The rival view was that prosecutorial elections were just a distraction, a sideshow. Incumbents hardly ever were thrown out of office, after all, and the campaigns focused on personalities, not on policies. ${ }^{4}$ So maybe electing prosecutors was just an empty exercise. The only thing that seemed clear was that picking prosecutors at the ballot box did nothing to make them better.

That was then. In 2013, a civil rights lawyer named Kenneth Thompson became Brooklyn's first African-American district attorney by defeating a six-term incumbent, Charles Hynes; Thompson's campaign focused on prosecutorial misconduct, discriminatory policing, and wrongful convictions under Hynes's watch. $^{5}$ The following year, Marilyn Mosby won election as Baltimore State's

* Stanley Morrison Professor of Law, Stanford Law School. I am indebted to Katherine DeMocker and Gina Elliot for superb research assistance.

1 See Michael Tonry, Prosecutors and Politics in Comparative Perspective, in ProseCUTORS And Politics: A Comparative Perspective 1 (Michael Tonry ed., 2012).

2 See, e.g., id.

3 See, e.g., Peter L. Davis, Rodney King and the Decriminalization of Police Brutality in America: Direct and Judicial Access to the Grand Jury as Remedies for Victims of Police Brutality When the Prosecutor Declines to Prosecute, 53 MD. L. REv. 271, 281-82 (1994).

4 See Ronald F. Wright, How Prosecutor Elections Fail Us, 6 Оніо ST. J. CRIM. L. 581 (2009); Ronald F. Wright, Beyond Prosecutor Elections, 67 SMU L. REV. 593 (2014).

5 See Donovan X. Ramsey, Kenneth Thompson: Could He Become the First Black District Attorney of Brooklyn?, GRIO (Sept. 19, 2013), http://thegrio.com/2013/09/19/kenneth-thompson-couldhe-become-the-first-black-district-attorney-of-brooklyn/ [https://perma.cc/TM5P-D8TA]; Vivian Yee, Thompson Defeats Hynes, Again, for Brooklyn District Attorney, N.Y. Times (Nov. 5, 2013), http://www.nytimes.com/2013/11/06/nyregion/thompson-claims-victory-over-hynes-again-for-

brooklyn-district-attorney.html; Two Cheers, ECONOMIST (Oct. 8, 2015), http://www.economist.com/ 
Attorney in part by promising aggressive prosecution of police misconduct. She made good on that promise just months after her election, securing swift indictments against four police officers implicated in the death of an AfricanAmerican man named Freddie Gray, arrested for what the officers thought was an illegal knife. ${ }^{6}$ In November 2015, Scott Colom defeated a tough-on-crime, longserving incumbent District Attorney in Mississippi after pledging to send fewer young offenders to prison. ${ }^{7}$ That same month, James Stewart became the first African-American District Attorney in the history of Caddo Parish, Louisiana, with a campaign emphasizing professionalism and ethics rather than convictions; he succeeded Dale Cox, an outspoken champion of the death penalty and long prison sentences. $^{8} \quad$ In March 2016, the incumbent District Attorney in Nueces County, Texas, Mark Skurka, lost his primary race to Mark Gonzalez, a defense attorney who lacked prosecutorial experience and had "not guilty" tattooed across his chest; Gonzalez had promised greater transparency and a crackdown on prosecutorial misconduct. ${ }^{9}$ Later that month Anita Alvarez failed in her bid to be reelected state's attorney in Cook County, Illinois; she lost largely because she had been insufficiently aggressive in prosecuting the police officer who shot and killed an unarmed Black teenager named Laquan McDonald. ${ }^{10}$ The victor in the primary,

news/united-states/21672292-best-way-reduce-prison-population-two-cheers [https://perma.cc/MZR6 -KPY7].

6 See John Woodrow Cox, Keith L. Alexander \& Ovetta Wiggins, Who is Baltimore State's Attorney Marilyn J. Mosby?, WASH. Post (May 1, 2015), https://www.washingtonpost.com/local/ who-is-baltimore-states-attorney-marilyn-j-mosby/2015/05/01/12be80e2-f013-11e4-8abc-d6aa3bad7 9dd_story.html [https://perma.cc/WA4S-SXWU].

7 See Jimmie E. Gates, Scott Colom Ousts Longtime DA Forrest Allgood, Clarion-Ledger (Nov. 6, 2015), http://www.clarionledger.com/story/news/2015/11/06/colom-ousted-da-forrest-allgood/ 75220072/ [https://perma.cc/CU4A-AAH7]; Leon Neyfakh, How to Run Against a Tough-on-Crime DA—and Win, SLATE (Nov. 12, 2015), http://www.slate.com/articles/news_and_politics/crime/2015/ 11/district_attorneys_scott_colom_proves_you_can_run_against_a_tough_on_crime.html [https://perma .cc/2SNX-8FEY].

8 See Alexandria Burris, Stewart Wins Caddo DA Race, Shreverort Times (Nov. 22, 2015), http://www.shreveporttimes.com/story/news/election/2015/11/21/caddo-da-election-runoff-results/75 899240/ [https://perma.cc/S28D-4P4A]; Darth Vader's Lament, EconOMist (Nov. 21, 2015), http:// www.economist.com/news/united-states/21678806-pains-americas-most-controversial-prosecutorand -strange-race-succeed.

9 See Krista M. Torralva, Skurka, Gonzalez Debate for DA Spot, CoRPus Christi CALler TiMES (Feb. 17, 2016), http://www.caller.com/news/local/skurka-gonzalez-debate-for-da-spot-2bf9c201 -4692-3288-e053-0100007f7dcf-369133251.html [https://perma.cc/8Y36-2JNY]; Krista M. Torralva, Defense Attorney Defeats Career Prosecutor in Nueces DA Primary, CORPUS CHRISTI CALLER TIMES (Mar. 1, 2016), http://www.caller.com/news/politics/elections/local/defense-attorney-defeats-careerprosecutor-in-nueces-da-primary-2c5e318e-995d-5a2a-e053-0100007fb176-370757171.html [https:// perma.cc/T44W-HT2H].

10 See Richard Pérez-Peña, Angered by Cities' Handling of Police Shootings, Voters Oust Two Prosecutors, N.Y. TIMES (Mar. 16, 2016), https://www.nytimes.com/2016/03/17/us/angered-bycities-handling-of-police-shootings-voters-oust-two-prosecutors.html. 
Kim Foxx, had also boasted of her work to reduce jail populations and remedy racial disparities in the criminal justice system. ${ }^{11}$ The same evening, voters in Ohio ousted Cuyahoga County Prosecutor Tim McGinty, who had declined to charge the officer who fatally shot a twelve-year-old African-American boy named Tamir Rice. ${ }^{12}$ In June 2016, the District Attorney in Santa Fe, Jennifer Padgett, lost her reelection bid to Marco Serna, who promised to refer all cases of police shootings to an outside agency. ${ }^{13}$ Two months later, in the judicial district including Jacksonville, Florida, Angela Corey became the first incumbent state attorney in modern times to lose a contested election. Despite solid backing from local law enforcement leaders and elected officials, Corey lost the Republican primary by thirty-eight points to a political novice, and much of the reason seems to have been Corey's harshly punitive record, particularly in prosecuting juveniles. $^{14}$

If winning a race for district attorney by promising less incarceration would have been "unthinkable in an earlier era," 15 it is not unthinkable today. ${ }^{16}$ Nor is getting turned out of office for being too soft on the police. ${ }^{17}$

In many ways, though, familiar politics of prosecution linger on. A prosecutor's job remains a steppingstone, and prosecutors continue to be celebrated mostly for winning convictions and stiff sentences, not for forbearance. When President Obama nominated Judge Merrick Garland for the Supreme Court, he praised the former federal prosecutor's experience "going after corrupt politicians and violent criminals," and singled out Garland's role in bringing

11 See Christie Thompson, Should Hard-Line Prosecutors Be Nervous?, MARShall Project (Mar. 16, 2016), https://www.themarshallproject.org/2016/03/16/should-hard-line-prosecutors-be-ner vous\#.h13abR8jK [https://perma.cc/R62X-3GXX].

12 Id.

13 See Phaedra Haywood, DA Race Heads for Photo Finish, SANTA FE NEw MeXICAN (June 7, 2016), http://www.santafenewmexican.com/news/local_news/da-race-heads-for-photo-finish/article_ b85eb6c1-fa43-5f1f-b5a0-6a1a9a20ceb8.html [https://perma.cc/XW8D-S9EJ].

14 See Larry Hannan \& Sebastian Kitchen, Northeast Florida Voters Kick Controversial State Attorney Angela Corey Out of Office, JACKSONVILLE.COM (Aug. 31, 2016), http://jacksonville.com/ news/metro/2016-08-30/story/northeast-florida-voters-kick-controversial-state-attorney-angela-corey [https://perma.cc/A4Z9-6B9H]; Jessica Pishco, Voters Have Ousted Notorious Florida Prosecutor Angela Corey, NATiOn (Aug. 31, 2016), https://www.thenation.com/article/voters-have-oustednotorious-florida-prosecutor-angela-corey/ [https://perma.cc/RBB7-3DJJ].

15 Neyfakh, supra note 7.

16 See Kim Bellware, It's Not Just Police Shooting Scandals: Why Prosecutors Across the Country are Finally Losing Elections, HufFington Post (Mar. 31, 2016), http://www.huffingtonpost .com/entry/prosecutors-losing-elections_us_56f03af3e4b084c67220ffa3 [https://perma.cc/X59L-4ZBD]. Colom suggested his election should be "a big signal to district attorneys and assistant DAs and judges, if they're paying attention, that there's been a shift in public opinion." Neyfakh, supra note 7.

17 See Editorial, Voters Tell Prosectors, Black Lives Matter, N.Y. TiMEs (Mar. 18, 2016), https://www.nytimes.com/2016/03/18/opinion/voters-tell-prosecutors-black-lives-matter.html. 
Timothy McVeigh, the Oklahoma City bomber, to justice. ${ }^{18}$ The Staten Island prosecutor who failed to secure an indictment against the officer who asphyxiated Eric Garner - an unarmed Black man arrested for selling untaxed cigarettes - is now in Congress. ${ }^{19}$ And prosecutors still often lobby against any weakening of tough sentencing laws. When Governor Jerry Brown of California proposed a ballot initiative to reduce prison overcrowding by giving some prisoners convicted of nonviolent offenses a chance at early release, the California District Attorney's Association filed suit to keep the measure off the ballot. ${ }^{20}$ Brown complained, with some justification, that "[t]he DAs have a long record of opposing sensible criminal justice reforms." ${ }^{21}$ And this was all before Donald Trump campaigned successfully for President as the "law and order candidate."

Have things really changed? Are we witnessing "the start of a new era of prosecutor elections"? ${ }^{22}$ And, if so, what should we make of the new politics of prosecution? This Essay begins to explore those questions by examining a series of recent elections - the ones mentioned above - in which voters have turned out prosecutors who seemed too punitive, or too protective of the police, and have elected district attorneys pledging reform. ${ }^{23}$ Part II of the Essay describes these races in detail. Part III then draws three tentative lessons from these elections. First, claims about the inexorable logic of criminal justice politics should be greeted with skepticism. Second, there is room for guarded optimism about electoral democracy as a tool for reforming prosecutors' offices, but voters need better tools for evaluating how those offices are performing. Third, as reformers increase their focus on prosecutorial elections, there is a danger worth bearing in mind: the risk that prosecutorial decision-making will become inappropriately politicized, particularly when elections focus on the handling or the outcome of isolated cases.

18 Press Release, White House Office of the Press Secretary, Remarks by the President Announcing Judge Merrick Garland as his Nominee to the Supreme Court (Mar. 16, 2016), https://obamawhitehouse.archives.gov/the-press-office/2016/03/16/remarks-president-announcingjudge-merrick-garland-his-nominee-supreme.

19 See Alexander Burns, Donovan, Staten Island Prosecutor, Wins Congressional Seat Grimm Held, N.Y. TIMES (May 5, 2015), https://www.nytimes.com/2015/05/06/nyregion/daniel-donovanelected-to-congress-from-new-york.html?_r=0 [https://perma.cc/9PWF-JSA2].

20 See Bob Egelko, Gov. Brown's Ballot Measure on Crime Remains Alive for Now, S.F. GATE (Mar. 10, 2016), http://www.sfgate.com/politics/article/Gov-Brown-s-ballot-measure-on-crimeremains-6880686.php [https://perma.cc/YDT8-PBY8].

21 Dan Walters, DAs and Brown on a Collision Course, SAN Diego UnION-Tri. (Feb. 12, 2016), http://www.sandiegouniontribune.com/opinion/commentary/sdut-walters-brown-district-attor neys-sentencing-2016feb12-story.html [https://perma.cc/LR3P-GFR9].

22 Thompson, supra note 11 (quoting Prof. Ronald Wright).

23 For more recent examples, see David Alan Sklansky, The Progressive Prosecutor's Handbook, 50 U.C. DAVIS L. REV. ONLINE 25, 25-26 (2017). I use the term "district attorney" throughout this essay to refer to a locally elected chief prosecutor, regardless of official title. 


\section{DATA POINTS}

\section{A. Kenneth Thompson Unseats Charles Hynes in Brooklyn}

If we are entering a new era in prosecutorial elections, the turning point may have been Kenneth Thompson's election as Brooklyn's District Attorney in 2013. Thompson defeated Charles Hynes, who was running for his seventh term. No incumbent district attorney had lost an election in Brooklyn for over a century, ${ }^{24}$ and Hynes was in many ways a particularly impressive incumbent. First elected in 1989 with the strong endorsement of The New York Times,${ }^{25}$ he had earlier made his reputation by successfully prosecuting the perpetrators of an infamous racial assault in Howard Beach. ${ }^{26}$ As District Attorney, he pushed for alternatives to incarceration,${ }^{27}$ opposed mandatory minimum sentences,${ }^{28}$ established a conviction integrity unit, ${ }^{29}$ and aggressively prosecuted the police officers who beat and sexually assaulted Abner Louima. ${ }^{30}$ As late as 2012 he was praised as a longtime champion of "smart on crime" approaches to prosecution ${ }^{31}$-approaches that replaced reflexive harshness with measured, evidence-based strategies to reduce offending and lower the financial and human costs of punishment. ${ }^{32}$

24 See Two Cheers, supra note 5.

25 See Editorial, Hynes for Brooklyn District Attorney, N.Y. Times (Sept. 5, 1989), http:// www.nytimes.com/1989/09/05/opinion/hynes-for-brooklyn-district-attorney.html [https://perma.cc/ 85UA-6C7X].

26 See Sam Roberts, A Racial Attack That, Years Later, Is Still Being Felt, N.Y. TIMES: CiTY Room (Dec. 18, 2011), http://cityroom.blogs.nytimes.com/2011/12/18/a-racial-attack-that-years-later -is-still-being-felt/ [https://perma.cc/GA2Y-DSFZ].

27 See Charles J. Hynes, Prosecutor Seeks Alternatives to Incarceration, 16 CRIM. JUST. 48 (2001); Nicole Lawson, It's a Man's Prison: How the Traditional Incarceration Model Fails Female Offenders in Kansas, 25 KAN. J.L. \& PUB. PoL'y 273, 279 (2016).

28 See Noah Mamber, Coke and Smack at the Drugstore: Harm Reductive Drug Legalization: An Alternative to a Criminalization Society, 15 CoRnell J.L. \& PUB. POL'y 619, 634 n.100 (2006).

29 See Michael Powell \& Sharon Otterman, Jailed Unjustly in the Death of a Rabbi, Man Nears Freedom, N.Y. TiMES (Mar. 20, 2013), http://www.nytimes.com/2013/03/20/nyregion/brook lyn-prosecutor-to-seek-freedom-of-man-convicted-in-1990-killing-of-rabbi.html [https://perma.cc/R4 VP-E7R8].

30 See Anthony V. Alfieri, Prosecuting Race, 48 DukE L.J. 1157, 1161 (1999).

31 See Roger A. Fairfax, Jr., The "Smart on Crime" Prosecutor, 25 Geo. J. Legal Ethics 905, 911 (2012).

32 Id.; Kamela D. Harris, Smart on Crime: A Career Prosecutor's Plan to MaKe Us SAFER (2009); Jonathan Simon, Beyond Tough on Crime: Toward a Better Politics of Prosecution, in Prosecutors and Democracy: A Cross-National Study (Máximo Langer \& David Alan Sklansky eds., forthcoming 2017) [hereinafter ProseCutors AND DEMOCRACY]. 
Hynes had also drawn criticism, though, for filing charges that appeared politically motivated ${ }^{33}$ and for his seeming reluctance to prosecute key supporters. ${ }^{34}$ Having served as District Attorney for more than two decades, he was dogged by allegations that his office had suppressed evidence and secured wrongful convictions. ${ }^{35}$ The conviction integrity unit that Hynes created wound up substantiating some of those allegations. ${ }^{36}$ He was defeated in the 2013 Democratic primary, and later in the general election, by Kenneth Thompson, a former federal prosecutor turned civil rights attorney who had worked on the federal criminal case against the officers who assaulted Abner Louima and later had represented Nafissatou Diallo, the hotel worker who claimed she had been sexually assaulted by Dominique Strauss-Kahn, the former head of the International Monetary Fund. ${ }^{37}$ Thompson's campaign focused on allegations of prosecutorial misconduct under Hynes's watch and Hynes's failure to rein in aggressive police tactics that disproportionately impacted minority youth. ${ }^{38}$

After taking office, Thompson largely ended prosecutions for low-level marijuana offenses, ${ }^{39}$ established a program to help offenders clear their records of open warrants, ${ }^{40}$ created a special court for "young adult" offenders, ${ }^{41}$ dramatically

33 See Christopher Ketcham, Meet the New Boss: Man vs. Machine Politics in Brooklyn, HARPER's MAG. (Dec. 2004), http://harpers.org/archive/2004/12/meet-the-new-boss-2/?single=1 [https://perma.cc/85Y8-LXC3].

34 See Vivian Yee, Challenger Wins Primary for Brooklyn District Attorney, N.Y. TIMES (Sept. 10, 2013), http://www.nytimes.com/2013/09/11/nyregion/challenger-wins-primary-for-brook lyn-district-attorney.html [https://perma.cc/2WNU-XNXK].

35 See Gail Robinson, The DAs of New York, Gotham GAZETTE (Mar. 7, 2005), http://www. gothamgazette.com/index.php/topics/2752-the-das-of-new-york [https://perma.cc/Y6LZ-F53F].

36 See, e.g., Powell \& Otterman, supra note 29.

37 See Yee, supra note 5; Yee, supra note 34.

38 See Yee, supra note 5; Yee, supra note 34. Hynes initially conceded the race to Thompson after losing the Democratic primary but then changed his mind and ran as the Republican and Conservative Party candidate. Thompson trounced Hynes in the general election, winning more than $70 \%$ of the vote. See Yee, supra note 5.

39 See Stephanie Clifford \& Joseph Goldstein, Brooklyn Prosecutor Limits When He'll Target Marijuana, N.Y. TIMES (July 8, 2014), http://www.nytimes.com/2014/07/09/nyregion/brooklyn-district -attorney-to-stop-prosecuting-low-level-marijuana-cases.html?_r=0 [https://perma.cc/DJT8-V2PE].

40 See Al Baker, Brooklyn Program Erasing Warrants for Low-Level Offenses, N.Y. TIMES (Oct. 7, 2015), http://www.nytimes.com/2015/10/08/nyregion/in-brooklyn-an-effort-to-erase-warrantsfor-low-level-offenses.html [https://perma.cc/MC3M-DSET].

41 See Thomas MacMillan, Brooklyn's New Approach to Youth Crimes, WALL ST. J. (June 30, 2016), http://www.wsj.com/articles/brooklyns-new-approach-to-youth-crimes-1462494059; Brooklyn DA's Office Announces Creation of New Young Adult Bureau, Brooklyn Daily Eagle (May 6, 2016), http://www.brooklyneagle.com/articles/2016/5/6/brooklyn-da\%E2\%80\%99s-office-announces -creation-new-young-adult-bureau [https://perma.cc/5HY5-S84X]. 
expanded and strengthened his office's conviction integrity unit, ${ }^{42}$ and repeatedly filed charges against police officers for misconduct in cases involving minority suspects. ${ }^{43}$ His handling of one of those cases - the fatal but apparently accidental shooting of an unarmed African-American man named Akai Gurley in a housing project stairwell by a rookie police officer named Peter Liang - brought Thompson criticism from both sides. Liang had immigrated from Hong Kong as a child, and many Asian Americans, both in New York City and around the United States, believed he was scapegoated because of his ethnicity; thousands took to the streets to protest his conviction. ${ }^{44}$ But when Thompson recommended against prison time in the case, ${ }^{45}$ and the judge put Liang on probation, many of the activists who had fought to oust Hynes now turned against his successor. ${ }^{46}$ Within weeks, there were calls for Thompson to resign, ${ }^{47}$ and the criticism persisted. ${ }^{48}$

The criticism Thompson drew about the Liang prosecution-first for pursuing a conviction, and then for recommending against prison time-highlights how difficult it can be to say what makes a prosecutor "progressive." It is worth remembering, too, that Charles Hynes was once admired as a thoughtful, reformminded prosecutor. Nonetheless, Thompson's victory over Hynes in 2013 represented a striking example of an entrenched incumbent district attorney losing to a challenger who ran on a platform of greater accountability for law enforcement, reviewing questionable convictions, and reining overly aggressive policing. And notwithstanding the controversy surrounding Thompson's handling of the case against Liang, the tone and direction of the Brooklyn District Attorney's office did seem to shift under Thompson, something most apparent, perhaps, in the dramatic expansion and strengthening of the office's conviction

42 See Matthew McKnight, No Justice, No Peace, New YORKER (Jan. 6, 2015), http://www. newyorker.com/news/news-desk/kenneth-thompson-conviction-review-unit-brooklyn [https://perma. cc/C82G-QQW6].

43 See Alan Feuer, Liberal Brooklyn Prosecutor Faces Unlikely Foes: Liberal Activists, N.Y. TIMES (May 16, 2016), http://www.nytimes.com/2016/05/17/nyregion/ken-thompson-liberal-brook lyn-prosecutor-faces-unlikely-foes-liberal-activists.html?_r=0 [https://perma.cc/74QP-S2UD].

44 See Oliver Milman, Thousands Join Rally Backing NYPD Officer Convicted of Manslaughter, GUARDIAN (Feb. 20, 2016), https://www.theguardian.com/us-news/2016/feb/20/nypdofficer-convicted-manslaughter-peter-liang-akai-gurley [https://perma.cc/R7UJ-FX78]; Sarah Maslin Nir \& David W. Chen, Many Asians Express Dismay and Frustration After Liang Verdict, N.Y. TIMES (Feb. 12, 2016), https://www.nytimes.com/2016/02/13/nyregion/many-asians-express-dismayand-frustration-after-liang-verdict.html [https://perma.cc/EVA3-VKQJ].

45 See Alan Feuer, Prosecutor Won't Seek Prison for Peter Liang, Ex-Officer Convicted in Killing, N.Y. TiMES (Mar. 23, 2016), http://www.nytimes.com/2016/03/24/nyregion/prosecutor-wontseek-prison-for-peter-liang-ex-officer-convicted-in-killing.html [https://perma.cc/3QB2-3JCY].

46 See Feuer, supra note 43.

47 See id.

48 See, e.g., Charles Barron, DA Thompson Driving Black Folk to the Edge, BLACK STAR NEws (June 18, 2016), http://www.blackstarnews.com/ny-watch/politics/da-thompson-driving-blackfolk-to-the-edge-charles-barron.html [https://perma.cc/5GZD-ENJV]. 
integrity unit. ${ }^{49}$ Thompson's tenure was short; he died of cancer at age 50 in October 2016 after serving only three years as District Attorney. By then, though, it appeared that Thompson's "more selective, less reflexively law-and-order approach to prosecution" stood a good chance of outlasting him in Brooklyn, in part because it was surfacing in other places as well. ${ }^{50}$

\section{B. Marilyn Mosby Takes Office in Baltimore}

The 2014 state's attorney race in Baltimore took place in a different context: rising crime and a new prosecutor who had yet to prove himself. Gregg Bernstein, who is white, had ousted a longtime incumbent in 2010, and claimed rising conviction rates since then. ${ }^{51}$ But violence had risen in the city, and Bernstein was criticized for failing to successfully convict certain people-particularly when he lost four sexual assault cases against a single person. ${ }^{52}$ Mosby successfully leveraged concerns about the crimes to win the Democratic primary, pledging to be tough on violent crime. ${ }^{53}$

Mosby, African-American and at the time 34, was a former city prosecutor. ${ }^{54}$ In addition to her "tough on crime" message, she promised to build community partnerships, create diversionary programs, and pledged to reduce recidivism. ${ }^{55}$ She also criticized Bernstein's decision not to prosecute police officers involved in the death of an African-American motorist named Tyrone West, and Bernstein's lack of transparency with West's family during the investigation. ${ }^{56}$ Mosby was

49 See, e.g., McKnight, supra note 42; E-mail from Jennifer Rogers, Executive Director, Center for the Advancement of Public Integrity (July 7, 2016) (on file with author).

50 Alan Feuer, Despite Ken Thompson's Short Stint as Brooklyn Prosecutor, Agenda May Endure, N.Y. TIMES (Oct. 10, 2016), https://www.nytimes.com/2016/10/11/nyregion/despite-kenthompsons-short-stint-as-brooklyn-prosecutor-agenda-may-endure.html [https://nyti.ms/2mpkrqo].

51 See Ian Duncan, Baltimore Prosecutor Hits Streets to Start Re-Election Campaign: Gregg Bernstein Says He Wants to Build on Successes of First Term, BALT. Sun (Apr. 19, 2014), http:// articles.baltimoresun.com/2014-04-19/news/bs-md-states-attorney-20140419_1_baltimore-prosecutor -re-election-campaign-northwest-baltimore [https://perma.cc/E9UM-R5QT].

52 See id.

53 See Luke Broadwater, Mosby's Focus on Crime Helped Unseat Bernstein, BaLt. Sun (June 25, 2014), http://www.baltimoresun.com/sports/bs-md-ci-mosby-analysis-20140625-story.html [https://perma.cc/ZL5Z-LFAJ]; Ian Duncan, Four Years In, Bernstein in Primary Fight for ReElection with Mosby, BALT. Sun (June 13, 2014), http://www.baltimoresun.com/news/maryland/ baltimore-city/bs-md-ci-states-attorney-election-20140613-story.html.

54 See Editorial, Baltimore City Endorsements, BALT. Sun (June 16, 2014), http://articles. baltimoresun.com/2014-06-16/news/bs-ed-baltimore-city-endorsements-20140616_1_liquor-boardwest-baltimore-vernon-tim-conway.

55 See id.

56 See Luke Broadwater \& Ian Duncan, Mosby Cut into Bernstein's Support in White Neighborhoods, Data Suggest, BALT. Sun (July 12, 2014), http://www.baltimoresun.com/bs-md-cimosby-race-20140712-story.html [https://perma.cc/G7DJ-34AV]. 
endorsed by former NAACP leader Kweisi Mfume, along with the Interdenominational Ministerial Alliance of Baltimore. ${ }^{57}$ She criticized Bernstein for being out of touch with the city, and attacked him for being too close to members of the Police Department. ${ }^{58}$ Bernstein raised three times more money than Mosby for the primary, ${ }^{59}$ but Mosby successfully used social media, personal interactions, and "targeted phone banks and emails" to get her message to her supporters. ${ }^{60}$ Bernstein largely ignored Mosby until late in the race. ${ }^{61}$

Assessing the significance of Mosby's victory is more complicated than in the case of Kenneth Thompson. Unlike Charles Hynes, Gregg Bernstein was relatively new to his office and had yet to prove himself, either for good or for bad. Mosby's campaign emphasized the "tough on crime" themes that are traditional in prosecutorial elections, but she also promised to be more aggressive in seeking charges against police officers, and that was a promise she fulfilled, with mixed results. Mosby declined to reopen the investigation into Tyrone West's death, ${ }^{62}$ but she was thrust into the national spotlight with her rapid filing of charges against six officers in the death of an unarmed black man named Freddie Gray. ${ }^{63}$ The case resulted in one hung jury, and three acquittals; ${ }^{64}$ following the third acquittal, Mosby dropped the charges against the remaining defendants. ${ }^{65}$

57 Luke Broadwater, Baltimore Ministers' Organization Endorses Gansler for Governor, BALT. Sun (Mar. 13, 2014), http://www.baltimoresun.com/news/maryland/politics/blog/bal-baltimore -ministers-organization-endorses-gansler-for-governor-20140313-story.html [https://perma.cc/L5MY -RRRT].

58 See Ian Duncan, Mosby Unseats Bernstein in City State's Attorney's Race, BALT. Sun (June 25, 2014), http://www.baltimoresun.com/news/maryland/politics/bs-md-ci-city-primary-2014 0624-story.html [https://perma.cc/5PZW-3D9R].

59 See id.

60 Danny Jacobs, Personal Approach Helped Mosby Campaign, DAILY REC. (June 25, 2014), http://thedailyrecord.com/2014/06/25/personal-approach-helped-mosby-campaign/.

61 See Broadwater, supra note 53; Wil S. Hylton, Baltimore vs. Marilyn Mosby, N.Y. TimeS (Sept. 28, 2016), https://www.nytimes.com/2016/10/02/magazine/marilyn-mosby-freddie-gray-balti more.html.

62 See Justin Fenton, Mosby: Tyrone West Case Won't Be Reopened Unless New Evidence Emerges, BALT. Sun (Apr. 14, 2016), http://www.baltimoresun.com/news/maryland/crime/bs-md-cityrone-west-mosby-20160414-story.html.

63 See, e.g., Sheryl Gay Stolberg \& Alan Blinder, A Rookie Prosecutor Takes a Stand and Surprises a Troubled City, N.Y. TIMES, May 2, 2015, at A1.

64 See Jess Bidgood, Another Baltimore Police Officer Acquitted in Freddie Gray Case, N.Y. Times (July 18, 2016), http://www.nytimes.com/2016/07/19/us/freddie-gray-baltimore-police.html [https://perma.cc/2RGZ-FPW7].

65 See Kevin Rector, Charges Dropped, Freddie Gray Case Concludes With Zero Convictions Against Officers, BALT. Sun (July 27, 2016), http://www.baltimoresun.com/news/maryland/freddiegray/bs-md-ci-miller-pretrial-motions-20160727-story.html. 
Meanwhile, 2015 saw Baltimore's homicide rate reach the highest level ever recorded. ${ }^{66}$

Many observers have suggested that Mosby moved too quickly and overcharged in the Freddie Gray case. ${ }^{67}$ By moving rapidly, though, Mosby helped to calm Baltimore in the wake of Gray's death. ${ }^{68}$ There was no violence or widespread unrest after the four trials in the case ended without guilty verdicts, nor when the remaining charges were dismissed. Even without convictions, Mosby's handling of the Gray case provided what many protesters in Ferguson, Missouri, and Staten Island complained they were denied: a public, adversarial examination of the circumstances surrounding the killing of an unarmed black man by the police. ${ }^{69}$ Still, the collapse of the criminal charges left Mosby's prospects for reelection in 2018 unclear. $^{70}$

\section{Scott Colom Ousts Forrest Allgood in Mississippi}

In November 2015, Scott Colom defeated Forrest Allgood, who since 1989 had been the district attorney in Mississippi's 16th Judicial District. There was not one particular controversy that galvanized an opposition to Allgood. Instead, the election was a response to a prolonged pattern of aggressive prosecutions and overturned convictions. Rather than seizing on a pre-existing movement calling for a change, Scott Colom appears to have been able to build support by drawing attention to this pattern and advocating for a different approach to prosecutions.

Allgood had been criticized for years by many different bodies, including the Mississippi Supreme Court, for actions such as continuing to use a discredited bite mark "expert" and refusing to accept DNA evidence of defendants' innocence. ${ }^{71}$ One man, Kennedy Brewer, was exonerated by DNA evidence in 2001, but Allgood continued to defend the conviction, delaying Brewer's release by seven

66 See Kevin Rector, Deadliest Year in Baltimore History Ends With 344 Homicides, BALT. SuN (Jan. 1, 2016), http://www.baltimoresun.com/news/maryland/baltimore-city/bs-md-ci-deadliestyear-20160101-story.html [https://perma.cc/WG8T-8P4D].

67 See Bill Turque \& Elise Schmelzer, After Dropping Charges, Marilyn Mosby Still Hailed as Both Heroine and Hack, WASH. POST (July 27, 2016), https://www.washingtonpost.com/local/mdpolitics/for-bold-young-prosecutor-effect-of-failed-prosecutions-unclear/2016/07/27/a7d0b6ac-540b11e6-bbf5-957ad17b4385_story.html [https://perma.cc/3762-6QJP].

68 See Stolberg \& Blinder, supra note 63; Turque \& Schmelzer, supra note 67.

69 See Turque \& Schmelzer, supra note 67.

70 See id. Hylton, supra note 61. For a nuanced assessment of Mosby's handling of the Freddie Gray case, and of her overall record, see Angela J. Davis, Prosecutors, Democracy and Race, in Prosecutors AND Democracy, supra note 32.

71 See Radley Balko, Election Results: One of America's Worst Prosecutors Lost Last Night, But One of Its Worst Attorneys General Won, WASH. Post (Nov. 4, 2015), https://www.washington post.com/news/the-watch/wp/2015/11/04/election-results-one-of-americas-worst-prosecutors-lost-last -night-but-one-of-its-worst-attorneys-general-won/?utm_term=.569ce783651c [https://perma.cc/7LH 5-YBEV]. 
years. ${ }^{72}$ Although Brewer was released in 2008, the case clearly still resonated in the area-Colom mentioned it frequently in his campaign, and posted a picture of Brewer on his campaign Facebook page. ${ }^{73}$ Colom charged that Allgood had "prosecuted lots of innocent people," and he stressed the state supreme court's reversal of convictions Allgood had obtained. ${ }^{74}$

Colom, who is African American, also ran on his own merits and goals. While only 32 , he had been a judge and then a city prosecutor for three years before the elections. ${ }^{75} \mathrm{He}$ had also been a Skadden fellow after law school. ${ }^{76} \mathrm{He}$ said that the "priorities and the policies that we've been doing [in the criminal justice system] the past 40 years haven't been working," although he also stressed that prosecutors have to be tough on violent crime. He said that he wanted to set up a special unit to focus on violent crime. ${ }^{77}$ Colom also wanted to increase the use of drug court for first time offenders, saying: "[w]e've lost the war on drugs .... Democrats and Republicans are coming together and realizing that the current approach is not working. It's my opponent's outdated model." 78 He complained that the 16th District had the highest incarceration rate in the state and blamed Allgood's policies. ${ }^{79}$ Colom won $53.9 \%$ of the vote in the election. ${ }^{80}$

Like Kenneth Thompson in Brooklyn, Colom won election as chief prosecutor based on a platform that emphasized criminal justice reform more than traditional "tough on crime" themes. Unlike Thompson, Colom was not running against a candidate tarred with accusations of political corruption; instead, the concerns about Allgood were that he was insufficiently measured, too aggressive and punitive. So Colom's election was particularly heartening to reformers. ${ }^{81}$ It is worth noting, though, that Colom's message was spread in part by radio and T.V. ads bought by Mississippi Safety and Justice, a PAC whose sole donor was a

72 Id.

73 Scott Colom, District Attorney, MS Judicial District 16, FACEBOOK (Oct. 26, 2015), https://www.facebook.com/colomforda16/photos/a.1418780985107819.1073741828.1418745308444 720/1513723738946876/?type=3\&theater [https://perma.cc/5F8C-B47N].

74 Andrew Hazzard, Dollars, Tensions Rise in D.A. Race, Columbus Dispatch (Oct. 17, 2015), http://www.cdispatch.com/news/article.asp?aid=45551 [https://perma.cc/Z5NU-P93B].

75 Andrew Hazzard, Colom Believes Time is Right for New Style, Columbus DisPatch (Oct. 28, 2015), http://www.cdispatch.com/news/article.asp?aid=45848 [https://perma.cc/W2MU-R9GJ].

76 Id.

77 Id.

78 Id.

79 Scott Colom, District Attorney, MS Judicial District 16, FACEBOOK (Oct. 7, 2015), https://www.facebook.com/colomforda16/photos/a.1418780985107819.1073741828.1418745308444 720/1506347906351126/?type=3\&theater [https://perma.cc/2A5M-AXNP].

80 Andrew Hazzard, Colom Takes D.A. Race, Columbus Dispatch (Nov. 3, 2015), http://www.cdispatch.com/news/article.asp?aid=45987.

81 See, e.g., Balko, supra note 71; Neyfakh, supra note 7. 
single out-of-state donor, George Soros. ${ }^{82}$ The PAC spent at least $\$ 89,000$ in support of Colom. ${ }^{83}$

\section{James Stewart Wins in Louisiana}

James Stewart, an African-American Democrat and lifelong resident of Caddo Parish, Louisiana retired in 2015 from a state judgeship he held for twenty-five years to run for District Attorney. ${ }^{84}$ While there were initially six candidates in the race, Stewart ended up in a run-off against Dhu Thompson, a Republican who had been in the district attorney's office for many years. Stewart got $41 \%$ of the vote in the primary, while Thompson had 36\%. ${ }^{85}$ In the run-off, Stewart received 55\% of the vote. ${ }^{86}$ He became the first Black district attorney of the history of Caddo Parish.

To a great extent, though, the election was less about Stewart or Thompson than about Acting District Attorney Dale Cox, a combative and outspoken champion of broader use of the death penalty. Cox told the Shreveport Times in March 2015 that Louisiana needs "to kill more people." picked up nationally, and subsequently Reprieve Australia released a study that showed that blacks had been disproportionately struck from jury panels in Caddo Parish from 2002-2012. ${ }^{88}$ Press also centered on the fact that Caddo Parish sent the most people to death row per capita of any county in the country. ${ }^{89}$ Cox, who had been the Acting District Attorney since April—and was responsible for more

82 See Hazzard, supra note 74.

83 See id.; Gates, supra note 7.

84 James Stewart, The Citizens of Caddo Deserve the Best, ShrevePORT Times (Nov. 18, 2015), http://www.shreveporttimes.com/story/opinion/2015/11/18/stewart-citizens-caddo-deserve-be st/76005932/ [https://perma.cc/WY65-2Z4X].

85 Victoria Shirley, Election Wrap Up: Caddo Parish Election Results, KSLA 12 NEwS (updated June 21, 2016), http://www.ksla.com/story/30344615/election-wrap-up-caddo-parish-elec tion-results [https://perma.cc/SM8G-7YQH].

86 Burris, supra note 8.

87 Zach Beaird, Dale Cox Brings Bad Press to Caddo, Shreveport Times (July 16, 2015), http://www.shreveporttimes.com/story/news/local/2015/07/15/dale-cox-brings-bad-press-caddo/3022 3399/ [https://perma.cc/D645-TQLS].

88 Alexandria Burris, Death Penalty, Civil Rights Cast Shadow on Caddo Parish, SHREVEPORT Times (Aug. 19, 2015), http://www.shreveporttimes.com/story/news/local/2015/08/18/ death-penalty-civil-rights-cast-caddo-parish-national-spotlight/31931697/ [https://perma.cc/95N6JM9P].

89 Janell Ross, Democrats Won Another Big Race in Louisiana-A Campaign Involving Race, Justice and the Death Penalty, WASH. Post (Nov. 23, 2015), https://www.washingtonpost.com/news/ the-fix/wp/2015/10/15/race-justice-and-the-death-penalty/ [https://perma.cc/TGP6-N5UD]. 
than a third of the death sentences handed down in Caddo Parish since $2011^{90}$ decided not to run to retain his position; he suggested that removing himself from the process might help "heal the community instead of continuing the controversy." 91 Thompson, a veteran of the District Attorney's office, took Cox's place as the establishment candidate.

The comments by Cox that drew so much attention to Caddo Parish followed the exoneration of Glenn Ford after he had served thirty years in solitary confinement. $^{92}$ Ford was released after investigators discovered exculpatory evidence that had not been pursued, and a prosecutor on the case admitted that he had ignored leads and struck potential Black jurors. ${ }^{93}$ For his part, Cox did not believe that anything immoral or illegal happened in Ford's prosecution, and Cox opposed state compensation for Ford. ${ }^{94}$ Cox also received national attention for prosecuting Rodricus Crawford for the death of Crawford's baby; doubts were raised about the scientific evidence used in that case. ${ }^{95}$ After successfully arguing for Crawford to receive the death penalty, Cox said he was "sorry that Louisiana has adopted lethal injection" because "Mr. Crawford deserves as much physical suffering as it is humanly possible to endure before he dies." 96 In yet another capital case, Cox was accused of physically threatening defense counsel ${ }^{97}-\mathrm{a}$ charge he more or less conceded. ${ }^{98}$

Stewart said he would reevaluate Crawford's case "to see if the verdict is defensible." ${ }^{99}$ The race focused less on specific cases, though, than on matters of policy and tone. Stewart and Thompson both supported the death penalty, but Stewart called for a change in the way that the prosecutor's office approached cases, saying that cases like Ford's showed the need for careful screening of cases

90 Rachel Aviv, Revenge Killing: Race and the Death Penalty in a Louisiana Parish, NEw YORKER (July 6 \& 13, 2015), http://www.newyorker.com/magazine/2015/07/06/revenge-killing [https:// perma.cc/CA7E-T7YH].

91 Beaird, supra note 87.

92 Ross, supra note 89.

93 A.M. "Marty" Stroud III, Lead Prosecutor Apologizes for Role in Sending Man to Death Row, SHREVEPORT Times (Mar. 20, 2015), http://www.shreveporttimes.com/story/opinion/readers/ 2015/03/20/lead-prosecutor-offers-apology-in-the-case-of-exonerated-death-row-inmate-glenn-ford/ 25049063/ [https://perma.cc/747U-NCTJ].

94 See Ross, supra note 89.

95 See Aviv, supra note 90.

96 See Aviv, supra note 90.

97 Alexandria Burris, Cox Accused of Threatening Defense Counsel in Death Row Case, SHREVEPORT TiMES (Oct. 28, 2015), http://www.shreveporttimes.com/story/news/watchdog/2015/10/ 28/dale-cox-eric-mickelson/74744842/ [https://perma.cc/54BZ-SR88].

98 See Darth Vader's Lament, supra note 8.

99 See Alexandria Burris, In-Depth: Caddo DA Candidates, Shreverort Times (Oct. 27, 2015), http://www.shreveporttimes.com/story/news/election/2015/10/27/caddo-da-runoff-stewartthompson/74611960/ [https://perma.cc/A35K-LDCF]. 
for compliance with ethical and professional standards. He did not say whether he would retain Cox, but pledged to "evaluate personnel," to change the "reality and [the] perception" that the office was out of step with the community. ${ }^{100} \mathrm{He}$ promised to restore the public's trust "by conducting prosecutions in [a] fair and legal manner," 101 and called for an end to the use of peremptory challenges of jurors. ${ }^{102}$ While he did support the death penalty, there was a public perception that he was less likely to aggressively pursue death sentences. ${ }^{103}$

Thompson, meanwhile, called for specialized prosecution units for domestic violence and white-collar crimes, and diversion programs that would keep firsttime offenders out of jail. ${ }^{104}$ But he called this "selective incarceration," rejecting the idea that "mass incarceration" was the norm. ${ }^{105}$ He agreed with Cox that Glenn Ford was not "factually innocent," saying he "was not guilty of first degree murder but he was not innocent of the crime." "106 This election, like Scott Colom's race in Mississippi, was the target of large donations by George Soros, who donated $\$ 916,000$ to a PAC supporting Stewart. ${ }^{107}$

It is too soon to say how much of a difference Stewart's election will make. During the campaign, a local political analyst predicted that neither Stewart nor Thompson would "deviate much from what's considered the norm in Caddo Parish," ${ }^{108}$ and Stewart's actions since taking office provide some vindication for that view. Within months of the election, Stewart had already decided to seek the death penalty against one accused killer, and to oppose Crawford's petition to have his sentence overturned. ${ }^{109}$ Although Stewart did say that "[e]conomically, we

100 Id.

101 Alexandria Burris, Death Penalty, Marijuana at Forefront in DA Forum, SHREVEPORT TiMES (Sept. 15, 2015), http://www.shreveporttimes.com/story/news/election/2015/09/15/death-penal ty-marijuana-forefront-da-forum/72292648/ [https://perma.cc/36MQ-85J3].

102 See Burris, supra note 99.

103 See Alexandria Burris, Nearing the Finish Line, SHrEVEPORT Times, Nov. 11, 2015, at 3A.

104 See Burris, supra note 99.

105 Burris, supra note 99.

106 Burris, supra note 99.

107 Alexandria Burris, Eyes of the Nation on Caddo DA Race, SHREvePORT Times (Oct. 26, 2015), http://www.shreveporttimes.com/story/news/election/2015/10/25/stewart-thompson-runoff/74 487742/ [https://perma.cc/8CPD-LVGX]; Ross, supra note 89.

108 Alexandria Burris, What Do You Need to Still Hear from the Caddo DA Candidates?, SHREVEPORT TIMES (Nov. 11, 2015), http://www.shreveporttimes.com/story/news/election/2015/11/ 10/caddo-da-candidates-comparison/75515322/ [https://perma.cc/N4EV-KY2X] (paraphrasing Brad Whitesides).

109 See Yolanda Young, America's Death Penalty Capital: Can a Black DA Really Change the System?, GUARDIAN (Mar. 13, 2016), https://www.theguardian.com/us-news/2016/mar/13/caddoparish-louisiana-death-penalty-capital-district-attorney [https://perma.cc/D2WT-HY4K]. 
can't afford mass incarceration," he suggested that was a "community problem" rather than the responsibility of any one office. ${ }^{110}$

Nonetheless, Stewart's election did seem to represent a rejection by voters of the hard-hitting, sanguinary approach to criminal justice personified by Dale Cox. As such - and notwithstanding the complicating factor of Soros's contributionsthe results in Caddo Parish provide another sign that the politics surrounding district attorney's races may be shifting, and that voters are looking for balance and accountability, rather than just toughness, from chief prosecutors.

\section{E. Mark Gonzalez Upsets Mark Skurka in Texas}

In March 2016, in what local media called "a huge upset," the well-known District Attorney of Nueces County, Texas, career prosecutor Mark Skurka, was turned out of office in the Democratic Primary. ${ }^{111}$ Skurka lost to Mark Gonzalez, a longtime criminal defense attorney with no prosecutorial experience with "not guilty" tattooed across his chest. ${ }^{112}$ During the campaign, Gonzalez embraced his identity as a hard-charging defense attorney. The principal issues on which he ran were prosecutorial misconduct and, in particular, the improper withholding of exculpatory evidence. He emphasized a string of cases in which convictions obtained in Nueces County had been overturned on appeal and the prosecutors had been accused of misconduct. Every prosecutor, Gonzalez said, should have "not guilty" tattooed "on their heart," because until convicted at trial, "everyone accused of a crime is not guilty." "In November 2016, Gonzalez edged out his Republican opponent in the general election. ${ }^{114}$

\section{F. Kim Foxx Trounces Anita Alvarez in Cook County}

One month after Mark Skurka lost in the Democratic Party primary to Mark Gonzalez in Nueces County, Texas, Anita Alvarez, the incumbent State's Attorney in Cook County, Illinois, was similarly turned out of office in a primary election. Alvarez's loss was national news. The flashpoint in the campaign was the killing of Laquan McDonald by a police officer, followed by a 13-month delay in bringing

110 Id.

111 See Andrew Ellison, Gonzalez Defeats Skurka in District Attorney Primary, KRISTV.COM (Mar. 2, 2016), http://www.kristv.com/story/31358310/race-for-nueces-county-district-attorney-amps -up-on-super-tuesday [https://perma.cc/523A-F52U]; Torralva, Skurka, Gonzalez Debate for DA Spot, supra note 9.

112 See Torralva, Skurka, Gonzalez Debate for DA Spot, supra note 9.

113 Id.

114 Krista Torralva, Gonzalez Soaks in Narrow Win, CoRPUs CHRisti Caller Times (Nov. 10, 2016), http://www.caller.com/story/news/local/texas/2016/11/09/gonzalez-soaks-narrow-win/9354 $2654 /$. 
charges against the officer. Alvarez did not announce that she was bringing charges until a judge ordered the release of the dashcam video of the shooting. ${ }^{11}$ But even before the release of that video sparked protests and calls for Alvarez to resign, it was clear that Kim Foxx represented a serious challenger. The Cook County Democratic party chose not to endorse anyone in the race in August, three months before the release of the McDonald video, ${ }^{116}$ and Alvarez had already been criticized for her "tough on crime" stance and seeming insensitivity to wrongful convictions. She had also been attacked for her office's handling of another police shooting case in 2015. In that case, Dante Servin was cleared for the killing of Rekia Boyd because the prosecutors had only brought an involuntary manslaughter charge; the judge said the charge should have been first-degree murder. ${ }^{117}$

Criticism of Alvarez mounted when the McDonald video was released and her political capital plummeted. Even before the video was released, Jesse Jackson had appeared alongside Foxx to call for Alvarez to resign. ${ }^{118}$ Following the release of the video in late November 2015, influential Latino politicians in Chicago also demanded that Alvarez step down. ${ }^{119}$ On December 1, Mayor Rahm Emanuel asked for and received the resignation of Police Superintendent Garry McCarthy, and protesters called for Alvarez and Emanuel to leave office as well. ${ }^{120}$ Shortly thereafter, Alvarez's campaign co-chair resigned, saying that Alvarez's actions show "that either she's callous to the sensitivities of different communities or she somehow just doesn't get it." ${ }^{21}$ On December 8th, African-American officials

115 See Fran Spielman, Garcia Wants Alvarez to Quit; State's Attorney's Political Base in Jeopardy, CHI. Sun-Times (Nov. 30, 2015), http://chicago.suntimes.com/politics/garcia-wantsalvarez-to-quit-states-attorneys-political-base-in-jeopardy/ [https://perma.cc/6L2T-83ZD].

116 See Kerry Lester, Cook County Democrats Won't Endorse Duckworth or Zopp in U.S. Senate Race, ChI. DAILY HeRALD (Aug. 19, 2015), http://www.dailyherald.com/article/20150819/ news/150818895/ [https://perma.cc/574V-NJCG].

117 See Steve Schmadeke, After Acquittal, Prosecutors Defend Decisions in Fatal Police Shooting, CHI. Sun-TIMES (Apr. 22, 2015), http://www.chicagotribune.com/news/ct-fatal-policeshooting-trial-met-20150421-story.html.

118 See Tina Sfondeles, Rev. Jesse Jackson Urges 'Police Shakeup' in Response to Cop's Fatal Shooting of Laquan McDonald, CHI. Sun-TimeS (Nov. 21, 2015), http://chicago.suntimes.com/news/ rev-jesse-jackson-urges-police-shakeup-in-response-to-cops-fatal-shooting-of-laquan-mcdonald/ [https://perma.cc/J9CC-KSP2].

119 See Spielman, supra note 115.

120 See Rick Pearson, Hal Dardick \& John Byrne, McDonald Case Adds to Alvarez's Campaign Woes, CHI. TRIB. (Dec. 7, 2015), http://www.chicagotribune.com/news/ct-anita-alvarezstates-attorneys-race-met-20151206-story.html; Kerry Lester, How McCarthy Firing Increases Pressure on Alvarez, CHI. DAILy HeRALD (Dec. 1, 2015), http://www.dailyherald.com/article/2015 1201/news/151209852/.

121 See Pearson, Dardick \& Byrne, supra note 120. 
representing city, county, and state government endorsed Foxx. ${ }^{122}$ In January, the Cook County Democratic Party endorsed Foxx. ${ }^{123}$ Black Lives Matter activists campaigned hard against Alvarez on social media. ${ }^{124}$

The anti-Alvarez campaign benefited from Foxx's strength as a candidate. Foxx had grown up poor, in Chicago public housing, and had years of experience as a prosecutor-albeit mostly a supervisor in the juvenile division, which meant that Alvarez had far more felony trial experience. ${ }^{125}$ Ultimately both major Chicago newspapers endorsed Foxx. ${ }^{126}$ Foxx also received six-figure donations from George Soros, the philanthropist Fred Eychaner, and an out-of-state super $\mathrm{PAC}^{127}$ - roughly matching the sums raised by Alvarez. ${ }^{128}$

In the end, Foxx received $62 \%$ of the vote in the Democratic Party primary and handily won the general election in November 2016. ${ }^{129}$ The high salience of the primary race was reflected in low ballot "roll-off": the fraction of people who returned ballots but did not vote for the state prosecutor dropped by about half compared to 2008, when Alvarez was first elected. ${ }^{130}$ Although the campaign raised larger issues about the criminal justice system, Foxx's large margin of victory appears to have owed a great deal to the publicity surrounding the Laquan McDonald case.

122 See Maudlyne Ihejirka, Black Officials Blast Alvarez on Police Misconduct Cases, Endorse Foxx, CHI. Sun-Times (Dec. 8, 2015), http://chicago.suntimes.com/politics/black-officials-blastalvarez-on-police-misconduct-cases-endorse-foxx/ [https://perma.cc/7W5H-LDS3].

123 See Hal Dardick, Endorsement Could Enhance Foxx's Name Recognition in State's Attorney Bid, CHI. TRIB. (Jan. 14, 2016), http://www.chicagotribune.com/news/local/politics/ct-cookcounty-democrats-endorse-foxx-over-alvarez-met-0115-20160114-story.html.

124 Deborah L. Shelton, Organizers Celebrate the Defeat of Anita Alvarez by Planning Their Next Steps, NATION (Mar. 16, 2016), https://www.thenation.com/article/organizers-celebrate-thedefeat-of-anita-alvarez-by-planning-their-next-steps/ [https://perma.cc/9FG7-7ELT].

125 Micah Uetricht, The Criminal-Justice Crusade of Kim Foxx, CHI. READER (Mar. 9, 2016), http://www.chicagoreader.com/chicago/kim-foxx-bid-unseat-anita-alvarez-cook-county/Content?oid $=21359641$ [https://perma.cc/JHM2-4GVP].

126 Editorial, Endorsing Kim Foxx: Time for a Change at State's Attorney, CHI. TRIB. (Feb. 26, 2014), http://www.chicagotribune.com/news/opinion/editorials/ct-kim-foxx-anita-alvarez-states-attor ney-endorsement-edit-20160226-story.html; Editorial, Kim Foxx for Cook County State's Attorney, CHI. Sun-Times (Feb. 23, 2016), http://chicago.suntimes.com/opinion/editorial-kim-foxx-for-cookcounty-states-attorney/.

127 John Byrne \& Hal Dardick, Foxx: Cook County State's Attorney Win About 'Turning the Page,' CHI. TRIB. (Mar. 16, 2016), http://www.chicagotribune.com/news/local/politics/ct-cookcounty-states-attorney-anita-alvarez-kim-foxx-met-0316-20160315-story.html; Sam Stecklow, A Look at the 'Dark Money' Behind Kim Foxx's States Attorney Campaign, ChiCAGoIST (Mar. 10, 2016), http://chicagoist.com/2016/03/10/kim_foxx_funding.php.

128 See Stecklow, supra note 127.

129 See Hal Dardick \& Matthew Walberg, Kim Foxx Declares Win in Cook County State's Attorney's Race, CHI. TRIB. (Nov. 8, 2016), http://www.chicagotribune.com/news/local/politics/ctcook-county-states-attorney-kim-foxx-election-met-1109-20161108-story.html.

130 See Shelton, supra note 124. 


\section{G. Tim McGinty Loses to Michael O'Malley in Ohio}

The same night that Kim Foxx defeated Anita Alvarez in Cook County, Illinois, Michael O'Malley unseated Timothy McGinty as Cuyahoga County Prosecutor in Ohio. The election result seemed almost entirely attributable to McGinty's failure to indict the police officer who fatally shot twelve-year-old Tamir Rice in November 2014. McGinty had been elected in 2012, running as a reformer. ${ }^{131}$ He had made good on some of his promises - for example, banning employees of the prosecutor's office from holding elected office, setting up conviction integrity and public corruption units, and increasing transparency. ${ }^{132}$ McGinty had also successfully pushed to clear the backlog of untested rape kits, resulting in more than 400 indictments. ${ }^{133}$

McGinty had a combative style, at times antagonizing judges, defense attorneys, and the police. ${ }^{134}$ But his loss seems overwhelmingly attributable to his handling of the Tamir Rice case - and, to a significantly lesser extent, his failed prosecution in an earlier case arising out of a police shooting. ${ }^{135}$ O'Malley declined to say, throughout the campaign, whether he thought criminal charges were warranted for Rice's death, ${ }^{136}$ but the election was less a comparison of the two candidates than a referendum on McGinty. O'Malley made few specific policy proposals - although he did advocate for a law that would require the Ohio Attorney General's Office to investigate all deadly shootings by police in the state ${ }^{137}$ and he suggested that he would convene a summit of municipal judges to

131 See Erick Trickey, Primary Concerns, Cleveland Mag. (Feb. 19, 2016), http://cleveland magazine.com/in-the-cle/politics/articles/primary-concerns1 [https://perma.cc/DJF9-GJW7].

132 See id.; Michael K. McIntyre, Prosecutor Timothy McGinty Pushes for Reform, but Presiding Judge John Russo Says His “Bully” Tactics Aren't Helping, Cleveland.com (Aug. 26, 2015), http://www.cleveland.com/tipoff/index.ssf/2015/08/prosecutor_timothy_mcginty_pus.html [https://perma.cc/5JYP-FWWQ]; Kyle Swenson, East Cleveland Man Busted by Corrupt Cops Freed by Prosecutor's Office, CLEVELAND SCENE (Feb. 24, 2016), http://www.clevescene.com/scene-andheard/archives/2016/02/24/east-cleveland-man-busted-by-corrupt-cops-freed-by-prosecutors-office [https://perma.cc/PUW4-K4UK].

133 See Nadia Pflaum, Cuyahoga Prosecutor Tim McGinty Touts Reduction in Rape Kits in Reelection Bid, POLITIFACT (Feb. 17, 2016), http://www.politifact.com/ohio/statements/2016/feb/17/ tim-mcginty/cuyahoga-prosecutor-touts-reduction-rape-kits-reel/ [https://perma.cc/W473-R6YX].

134 See, e.g., McIntyre, supra note 132; Tom Beres, Why Mike O'Malley Will Replace Tim McGinty as Cuyahoga County Prosecutor, WKYC.COM (Mar. 16, 2016), http://www.wkyc.com/news/ politics/why-is-mike-omalley-going-to-replace-tim-mcginty-as-cuyahoga-co-prosecutor/85609823.

135 See Bellware, supra note 16.

136 See David Petkiewicz, Michael O'Malley for Cuyahoga County Prosecutor in the Democratic Primary: An Opposing View, Cleveland.com (Feb. 25, 2016), http://www.cleveland. com/opinion/index.ssf/2016/02/opposing_view_michael_omalley.html\#6 [https://perma.cc/JPN4-XNRX].

137 See id.; Joshua Gunter, Michael O'Malley Topples Cuyahoga County Prosecutor Timothy McGinty, Cleveland.Com (Mar. 16, 2016), http://www.cleveland.com/metro/index.ssf/2016/03/ michael_omalley_topples_cuyaho_1.html [https://perma.cc/5MG5-ZBGX]. 
ensure that low-level offenses were handled consistently across the county. ${ }^{138}$ But O'Malley "campaigned hard in predominantly black neighborhoods in Cleveland and near east-side suburbs," and he received key endorsements from leaders of the African-American community. ${ }^{139}$

O'Malley's focus on Black communities was successful. He won all 282 majority-Black precincts, which was enough to give him almost $56 \%$ of the overall vote, even though McGinty edged him out in precincts where Black voters were a minority. ${ }^{140}$ O'Malley faced no challenger in the general election. ${ }^{141}$ His primary victory may be the clearest example of voters mobilizing out of anger about one particular event. It does not appear that McGinty would have been ousted, or O'Malley elected, without the catalyst of the Tamir Rice shooting.

\section{H. Marco Serna Wins in Santa Fe}

In June 2016, former prosecutor Marco Serna narrowly won a three-way primary race for the Democratic Party nomination for District Attorney in New Mexico's First Judicial District, which includes Santa Fe. ${ }^{142}$ The district is heavily Democratic, and Serna went on to win general election in a landslide. ${ }^{143}$ In the primary, he defeated the recently appointed incumbent, Jennifer Padgett, and another former prosecutor, Maria Sanchez-Gagne. ${ }^{144}$ Much of the primary campaign focused on the handling of criminal cases arising from officer-involved shootings. ${ }^{145}$ All three candidates agreed that investigatory grand juries should no

138 Sam Allard, Tim McGinty, Mike O'Malley Trade Blows at City Club Prosecutor Debate, Cleveland ScEne (Feb. 23, 2016), http://www.clevescene.com/scene-and-heard/archives/2016/02/23/ tim-mcginty-mike-omalley-trade-blows-at-city-club-prosecutor-debate [https://perma.cc/WA64-X72E].

139 Gunter, supra note 137; Eric Heisig, Michael O'Malley Begrudgingly Wins Support of Some Cleveland Pastors, ClEveland.COM (Jan. 22, 2016), http://www.cleveland.com/court-justice/ index.ssf/2016/01/michael_omalley_begrudgingly_w_1.html [https://perma.cc/AKD8-WH8X].

140 See Rich Exner, Vote in Black Communities Sweeps Michael O'Malley to Victory Over Cuyahoga County Prosecutor Timothy McGinty, Cleveland.COM (Mar. 17, 2016), http://www.cleve land.com/datacentral/index.ssf/2016/03/vote_in_black_communities_swee.html [https://perma.cc/F9 5K-K6G9].

141 See id.

142 Andrew Oxford, Serna, Young Dem Who Survived Tight DA Primary, Now Faces GOP Challenge, SANTA FE NEw MEXICAN (June 9, 2016), http://www.santafenewmexican.com/news/local _news/serna-young-dem-who-survived-tight-da-primary-now-faces/article_efd1ddb2-990c-5591-831 9-2513736df154.html [https://perma.cc/KF76-9X8G]; Haywood, supra note 13.

143 See Phaedra Haywood, Serna Runs Away With DA Race, SAnTa Fe New MeXICAn (Nov. 8, 2016), http://www.santafenewmexican.com/news/local_news/serna-runs-away-with-da-race/article_2 dabaf39-dce5-56a8-833b-618148f200da.html [https://perma.cc/69BQ-MPGS].

144 See Haywood, supra note 13; Oxford, supra note 142.

145 See Jeff Proctor, Puff of Smoke: How the Justice System was Designed to Clear the Cop Who Killed Jeanette Anaya, SANTA FE REP. (Mar. 23, 2016), http://www.sfreporter.com/santafe/ 
longer be used to investigate police shootings. ${ }^{146}$ Serna, though, was the only candidate who pledged to turn all such cases over to an independent agency for investigation. ${ }^{147}$ More generally, Serna promised to be "smart on crime, not just tough on crime." 148

Serna came from a politically connected family, raised far more money than his opponents, and was the first to challenge Padgett. ${ }^{149}$ Nonetheless, his victory is one more piece of evidence that the political playbook is changing in prosecutorial elections: that candidates can win by promising less punitive practices and more independence from the police, and that incumbents can lose by being too propolice or too "tough on crime."

\section{Angela Corey is Defeated in Florida}

In August 2016, for the first time in modern history, voters ousted the incumbent state attorney in Florida's Fourth Judicial District, which includes Jacksonville, Florida. Despite solid backing from local law enforcement and elected leaders, Angela Corey lost the Republican primary by thirty-eight points to a corporate lawyer and former prosecutor, Melissa Nelson, who promised to restore integrity to the state attorney's office and to regain the community's trust. ${ }^{150}$ The primary result effectively decided the election because there was no Democratic Party candidate for the office.

Corey had become notorious for her hardline practices, particularly with regard to prosecution of juveniles; criminal justice reformers campaigned against her and welcomed her defeat. ${ }^{151}$ But Corey had also earned the enmity of gun rights activists for her prosecution of George Zimmerman, the volunteer security

article-11737-puff-of-smoke.html [https://perma.cc/8D9T-GD9G]; Andrew Oxford, DA Hopefuls Strive to Distinguish Themselves at Forum, SANTA Fe New MEXICAN (Apr. 20, 2016), http://www .santafenewmexican.com/news/local_news/da-hopefuls-strive-to-distinguish-themselves-at-forum/ article_5e4defbe-83d3-59f5-b1f6-6d4b66478db5.html [https://perma.cc/UR8U-WFSL].

146 See Oxford, supra note 145.

147 See id.

148 Phaedra Haywood, DA Candidate Serna Plans to "Be Smart on Crime," SANTA Fe NEw MeXiCAN (May 14, 2016), http://www.santafenewmexican.com/news/local_news/da-candidate-sernaplans-to-be-smart-on-crime/article_3fefaf29-4333-5435-b9f5-734b5ea36a4e.html [https://perma.cc/ 333N-TFS9].

149 See Oxford, supra note 145.

150 See Hannan \& Kitchen, supra note 14; Leon Neyfakh, Is the Defeat of America's "Cruelest Prosecutor" in Florida Really a Victory for Criminal Justice Reform?, SLATE (Sept. 1, 2016), http://www.slate.com/articles/news_and_politics/politics/2016/09/melissa_nelson_ousts_angela_core y_is_it_a_victory_for_criminal_justice.html [https://perma.cc/R6EZ-34PV].

151 See Emily Bazelon, Where the Death Penalty Still Lives, N.Y. Times MAG. (Aug. 23, 2016), http://www.nytimes.com/2016/08/28/magazine/where-the-death-penalty-still-lives.html; Pishco, supra note 14. 
guard who had fatally shot a Black teenager named Trayvon Martin, and the National Rifle Association endorsed her opponent. ${ }^{152}$ Nelson, for her part, "ran a pretty conventional prosecutor's campaign, criticizing her opponent's integrity and judgment, while repeatedly emphasizing her own unforgiving stance on crime." ${ }^{253}$ After Nelson won, her spokesman cautioned that the result should not be seen as "some success of the left." 154 But Nelson has made clear that she wants to be more selective in seeking the death penalty and in charging juveniles as adults; she has also expressed interest in establishing Florida's first conviction integrity unit. ${ }^{155}$ Her victory thus appears to be one more piece of evidence that in the current political climate incumbents can lose prosecutorial elections, even when backed by law enforcement officials, and that an overly harsh stance can be a political liability. ${ }^{156}$

\section{LESSONS}

The prosecutors who have won election on "progressive" platforms are an eclectic group. Some, like Kenneth Thompson in Brooklyn, Scott Colom in Mississippi, James Stewart in Louisiana, and Mark Gonzalez in Texas, campaigned against overly aggressive prosecutions. Others, like Marilyn Mosby in Baltimore, Kim Foxx in Illinois, Michael O'Malley in Ohio, and Marco Serna in Santa Fe, focused on the failure of the incumbents to be aggressive enough in prosecuting police officers. Scott Colom, James Stewart, and Kim Foxx were supported by out-of-state financing; the other candidates apparently were not. Some of these candidates, like Thompson, Colom, Foxx, and O'Malley, were running against discredited incumbents; that was not true, though, for Stewart, Gonzalez, or Serna, nor, really, for Mosby. Specific, local circumstances played a part in many of these election results: the corruption allegations against Charles Hynes in Brooklyn, the inflammatory rhetoric of Forrest Allgood in Mississippi, the family connections of Marco Serna, the high-profile shootings by the police in Chicago and Cleveland, and the opposition of gun rights activists to Angela Corey. All of these factors make it hazardous to draw broad conclusions from this

152 See Neyfakh, supra note 150.

153 Id.

154 Id. (quoting Brian Hughes).

155 See Larry Hannan, New State's Attorney Faces Expectations, Potential Pitfalls as She Takes Office, JACKSONVILLE.COM (Jan. 2, 2017), http://jacksonville.com/news/2017-01-02/new-stateattorney-faces-expectations-potential-pitfalls-she-takes-office [https://perma.cc/G9QL-FYWP].

156 See Pishco, supra note 14. 
relatively small set of races. We are talking here about roughly a dozen elections, and there are somewhere around 2,500 elected prosecutors in the United States. ${ }^{157}$

Still, some tentative inferences seem warranted, in part precisely because the races reviewed above are so varied, not just in how they played out, but in where they occurred: in the East, in the West, in the North, and in the South, in large cities and in less populous areas. Here are three provisional lessons.

\section{A. The Politics of Criminal Justice are Not Written in Stone}

It can be hard to tell the temporary from the permanent. For decades, rates of incarceration in the United States were relatively stable. It made sense to think the stability resulted from enduring processes of equilibration within the criminal justice system; a famous paper by distinguished criminologists in 1973 advanced precisely that hypothesis. ${ }^{158}$ Then rates of incarceration skyrocketed, and they continued to climb even when crime rates began to plummet. ${ }^{159}$ It began to seem that the criminal justice system operated like a one-way ratchet: penalties increased, but never declined.

Criminal justice scholars found explanations for the ratchet in the politics of punishment. "Tough on crime" repeatedly proved a winning issue at the polls because there was never much sympathy for "criminals," considered as a class, and the upfront price of making penalties harsher was approximately zero. The eventual costs of over-incarceration were massive, in human terms as well as economic terms, ${ }^{160}$ but enacting mandatory minimum penalties was free in the short term, and the short term was what registered with politicians. ${ }^{161}$ The

157 See Nicolas Fandos, A Study Documents the Paucity of Black Elected Prosecutors: Zero in Most States, N.Y. TimES (July 7, 2015), http://www.nytimes.com/2015/07/07/us/a-study-documentsthe-paucity-of-black-elected-prosecutors-zero-in-most-states.html.

158 See Alfred Blumstein \& Jacqueline Cohen, A Theory of the Stability of Punishment, $64 \mathrm{~J}$. CRIM. L. \& CRIMINOLOGY 198 (1973).

159 See, e.g., Alfred Blumstein, Racial Disproportionality of U.S. Prison Populations Revisited, 64 U. Colo. L. Rev. 743 (1993); Franklin E. Zimring, The Scale of Imprisonment in the United States: Twentieth Century Patterns and Twenty-First Century Prospects, 100 J. CRIM. L. \& CRIMINOLOGY 1225 (2010).

160 See, e.g., Christian Henrichson \& Ruth Delaney, Vera Inst. of Justice, The Price of PRISONS: What INCARCERATION COSTS TAXPAYERS (2012); JONATHAN SimON, MASS INCARCERATION on Trial: A Remarkable Court Decision and the Future of Prisons in America (2014); Dorothy E. Roberts, The Social and Moral Cost of Mass Incarceration in African American Communities, 56 Stan. L. Rev. 1271 (2004); Ta-Nehisi Coates, The Black Family in the Age of Mass Incarceration, ATLANTIC (Oct. 2015), http://www.theatlantic.com/magazine/archive/2015/10/theblack-family-in-the-age-of-mass-incarceration/403246/ [https://perma.cc/9P34-CJHM].

161 See, e.g., Rachel Barkow, Federalism and the Politics of Sentencing, 105 Colum. L. Rev. 1276 (2005); Sara Sun Beale, What's Law Got to Do With It? The Political, Social, Psychological and Other Non-Legal Factors Influencing the Development of (Federal) Criminal Law, 1 BuFF. Crim. L. Rev. 23, 58 (1997); William J. Stuntz, The Pathological Politics of Criminal Law, 100 Mich. L. REV. 505 (2001). 
politicians that mattered here included legislators, obviously, ${ }^{162}$ but also that peculiarity of the American criminal justice system, elected prosecutors. Prosecutors, in fact, were doubly important. Not only did they choose how and when the criminal laws on the books would actually be applied, but they lobbied for stiff mandatory penalties ${ }^{163}$ - both to burnish their political credentials as crime fighters and because their jobs were easier when they could use the threat of long prison sentences to coerce guilty pleas. ${ }^{164}$ Moreover, district attorneys were elected countywide. In most places that meant that white, suburban voters fearful of crime would ensure that "tough on crime" prosecutors took and held office, even if inner city, minority voters - who might be more likely to share a "linked fate" with criminal defendants ${ }^{165}$ - came to believe that penalties were too severe.

Most scholars recognized that the one-way ratchet was a relatively new feature of American criminal justice; some pointed out, in fact, how sharp a break it was with the past. ${ }^{166}$ Nonetheless, the impression left by much criminal justice scholarship, beginning in the late 1970s, was that ever-lengthening sentences and ever-expanding prisons were the new normal. It was hard to see a way out. Or, if there was a way out, it was budgetary: draconian punishment might get to be too expensive, particularly in an economic downturn. If voters ever turned away from "tough on crime" policies, it would be because they no longer seemed affordable. A decade into the new century, there were signs that, in fact, support was growing for an approach to criminal justice that emphasized "economic rationality" and "return on investment" " without necessarily throwing into doubt any of the underlying normative commitments of the older, "tough on crime" approach. ${ }^{168}$

Marco Serna leaned heavily on "smart on crime" rhetoric in his victorious primary campaign in Santa Fe; Michael O'Malley did the same in Cleveland. But the handling of officer-involved shootings - no part of the "smart on crime" agenda - was a key factor in both of these elections, as well. In Cleveland, in fact, it was more or less the only issue. That issue also played a large role in Kim Foxx's defeat of Anita Alvarez in Cook County, Illinois, and it was part of Marilyn

162 See, e.g., Stuart A. Scheingold, The Politics of Street Crime: Criminal Process AND Cultural Obsession (1991); Donald A. Dripps, Criminal Procedure, Footnote Four, and the Theory of Public Choice; or, Why Don't Legislatures Give a Damn about the Rights of the Accused?, 44 SYRACUSE L. REV. 1079 (1993); Barkow, supra note 161.

163 See, e.g., Jonathan Simon, Governing Through Crime: How the War on Crime Transformed AMERICAN DEMOCRACY AND CREATED A Culture OF FEAR 37-60 (2007).

164 See, e.g., William J. Stuntz, The Political Constitution of Criminal Justice, 119 HARV. L. REV. 780 (2006); Barkow, supra note 161; Stuntz, supra note 161.

165 E.g., Tracey L. Meares, Place and Crime, 73 Chi.-Kent L. Rev. 669, 682 (1998).

166 See, e.g., David Garland, The Culture of Control: Crime and Social Order in CONTEMPORARY SOCIETY (2001); SIMON, supra note 163.

167 See also HAdAR Aviram, ChEAP ON CRIME: ReCESSION-ERA POlitics AND THE Transformation of AMERICAN PUnishment (2015); Simon, supra note 32.

168 See Simon, supra note 32. 
Mosby's successful campaign platform in Baltimore. The emphasis on police violence in these elections fits what Jonathan Simon identifies as "a revitalized sense of prosecutors as quasi-judicial overseers of the criminal process, and guarantors of its integrity against the potential excesses of policing and punishment."169 The same can be said for Kenneth Thompson's successful race in Brooklyn, and the victories of Scott Colom in Mississippi, James Stewart in Louisiana, and Mark Gonzalez in Texas; each of these candidates won office by promising, in part, to reduce prosecutorial misconduct, excessive punishment, or overly aggressive, racially disproportionate police tactics. Simon argues plausibly that the renewed emphasis on prosecutors as guarantors of fairness is part of a new mindset among some prosecutors, distinct from and more radical than "smart on crime" - a "willingness to invoke the language of dignity and empathy.", "s0

Simon stresses the contingency and unpredictability of current trends in prosecutorial politics; he warns that the "dominant strategy" of prosecutors "has been to hold tight to the politics of tough on crime," and he suggests that public receptivity to new directions in criminal justice may not last. ${ }^{171}$ The contingency is precisely the point, though. The recent spate of elections in which prosecutors have won office by promising not toughness, but criminal justice reform-more scrutiny of the police, more vigilance against wrongful convictions, less aggressive patrolling of minority neighborhoods, or some mixture of these changes - suggests we should be skeptical of the idea that the contemporary politics of criminal justice have an inexorable logic. Nothing guarantees the spread of the emerging political themes Simon identifies, particularly given Donald Trump's explicit embrace of "law and order" politics in his successful presidential campaign. But nothing guarantees their ultimate failure, either.

\section{B. Democratic Oversight of Prosecutors is Worth Strengthening}

Election of prosecutors does not have to be either meaningless or pernicious. It does not seem to have been meaningless or pernicious recently in Baltimore, Brooklyn, Chicago, Cleveland, or Santa Fe, nor in Caddo Parish, Louisiana, Nueces County, Texas, Mississippi's 16th Judicial District, or Florida's Fourth Judicial District. The election results in these places suggest that the voting booth can be an important tool for overseeing prosecutors and making them accountable. ${ }^{172}$

\section{$169 I d$.}

${ }^{170}$ Id. Simon finds evidence of an emerging "prosecutorial politics of dignity" largely in initiatives by the United States Department of Justice and in the positions taken by San Francisco's District Attorney, George Gascón. See also Davis, supra note 70 (describing efforts by John Chisholm, Milwaukee's District Attorney, to reduce racial disparities in prosecution).

171 Simon, supra note 32.

$172 C f$. Davis, supra note 70 (concluding that "[a]lthough the electoral process for state and local prosecutors has its flaws, it presents the best opportunity for holding prosecutors accountable"). 
Still, the tool has significant limitations. Perhaps the most serious is that voters generally are poorly positioned to assess the performance of an elected prosecutor. Prosecutors do much of their most important work not in open court but behind closed doors: that is where they consult with police officers, make charging decisions, determine what evidence needs to be disclosed, and hammer out plea deals. And prosecutors' offices tend to be secretive and opaque, far more so than even most police departments. As a consequence, the public often lacks basic information about how a district attorney's office is operating.

Moreover, it is not even clear what information the public should want or should care most about; there is remarkably little consensus about what distinguishes good prosecutors' offices from bad ones. It is not just that people disagree; most of us have, within ourselves, conflicting expectations for prosecutors. We want them to be zealous advocates and dispassionate ministers of justice, champions of justice and instruments of mercy, creatures of the law and exercisers of discretion. ${ }^{173}$ All of this- the lack of transparency, the disagreements and conflicting expectations about how prosecutors should do their jobs - makes it difficult to assess the ultimate significance of Kenneth Thompson's victory in Brooklyn, Marilyn Mosby's in Baltimore, or James Stewart's in Mississippi-or, really, any of the election results we have been discussing.

A handful of scholars have been calling on prosecutors' offices for years to be more transparent - to make regular public disclosures of their policies and case statistics. Some prosecutors have embraced that goal: Marilyn Mosby, in particular, campaigned in part by promising greater transparency, and so did Mark Gonzalez in Texas. Before his defeat by Michael O’Malley, Timothy McGinty had worked to make the Cuyahoga County District Attorney's Office more transparent. In different ways, Mosby's case and McGinty's case both make clear, if it needed clarifying, that transparency is not a panacea, especially when even scholars cannot agree what information is most important for prosecutors to share. ${ }^{174}$ And even if the right information is disclosed, there is no guarantee the public will care about it. Dry statistics rarely grab the kind of attention that isolated, sensational cases receive. Kenneth Thompson received far more attention for his handling of the Liang case than for his strengthening of his office's conviction integrity unit; and Marilyn Mosby's future political prospects probably will have less to do with Baltimore's crime rate, or her day-to-day management of her office, than with the long legal fallout from the death of Freddie Gray. ${ }^{175}$

If elections are to serve more than sporadically as constructive tools for overseeing prosecutors, voters will need better ways to evaluate prosecutors' performance, not just in sensational cases or in press conferences, but in the

173 See David Alan Sklansky, The Nature and Function of Prosecutorial Power, 117 J. CRIM. L. \& CRIMINOLOGY (forthcoming 2017), http://ssrn.com/abstract=2770815.

174 See id.

175 See Hylton, supra note 61. 
routine administration of justice by the line attorneys they supervise: the office's charging decisions, its discovery practices, its plea bargaining policies, and its courtroom advocacy. For the most part, voters today have no real ability to assess any of this.

One possible response would be a ranking or rating system for prosecutor's offices, assembled and disseminated by an impartial organization-ideally a research university or a well-respected public policy institute. ${ }^{176}$ Constructing a credible scorecard of this kind would be challenging, in part because much of what prosecutors do remains hidden from view, and in part because it is unclear, in so many ways, what the public wants, or should want, from prosecutors. Any ranking or rating system would be reductive at best, leaving out important aspects of an elected prosecutor's performance and measuring other aspects imperfectly. These are familiar problems, though, when constructing a public policy scorecard, and scorecards have nonetheless proven promising tools for driving reform and empowering public oversight in a range of other policy areas. ${ }^{177}$ The right question to ask about a proposed public policy scorecard is, "As opposed to what?"178 — not how much the scorecard misses or oversimplifies but whether it improves on the impressionistic evaluations that could or would be made in its absence.

That is a low bar to clear when considering a possible ranking or rating system for elected prosecutors. The baseline here is a system where voters in most cases have virtually no meaningful way to assess the performance of their elected prosecutors. The elections I have discussed are, to a great extent, exceptions that prove the rule: situations in which, for example, a sensational case, or accumulating allegations of corruption or malfeasance, or a series of public statements so alarmingly sanguinary they draw international attention, drive an incumbent from office. It should be possible to improve on that.

We may want more from elected prosecutors than running their offices well; we may want them, for example, to lead efforts to reform the criminal justice system. Still, one thing that should matter in assessing a district attorney is how well his or her office is run, the quality of justice it dispenses day in and day out. And despite our conflicting expectations for prosecutors, and the disagreements about how those expectations should be reconciled, it should be possible to devise a broadly acceptable set of criteria for assessing prosecutors' offices. Those criteria might include, for example: (1) professional effectiveness in developing and defending cases, and in defending verdicts, (2) compliance with procedural

176 See David Alan Sklansky, Unpacking the Relationship Between Prosecutors and Democracy in the United States, in PROSECUTORS AND DEMOCRACY, supra note 32, http://ssrn.com/ abstract $=2829251$.

177 See, e.g., id.; Heather K. Gerken, The Democracy Index: Why Our Election System Is FAILING AND How TO FIX IT (2009).

178 GERKEN, supra note 177, at 102. 
rules and discovery obligations, (3) lack of racial or political bias, (4) willingness to acknowledge mistakes and vigilance in correcting errors, and (5) proportionality in punishments sought. Are there measurable proxies for these desiderata-not perfect proxies, but proxies that are better than nothing? We will not know unless we look.

\section{There are Dangers in Politicizing the Handling of Individual Cases}

The alternative to developing some sort of ranking or rating system for prosecutors' offices is for voters to continue relying on campaign rhetoric and isolated, sensational cases in deciding whether to reelect a district attorney. That seems undesirable not just because it ignores too much and lets too many elected prosecutors off the hook, but because it can inappropriately politicize the treatment of individual defendants.

The danger of politicizing the handling of particular cases is, in fact, a worrisome aspect of the growing attention voters seem to be paying to prosecutorial elections. In 2015, the district attorney race in Montgomery County, Pennsylvania, was widely seen as, in part, a referendum on whether Bill Cosby should be prosecuted for sexual assault. The challenger, First Assistant District Attorney Kevin Steele, won election after repeatedly attacking his boss, incumbent District Attorney Bruce Castor, for failing to file charges against Cosby a decade earlier, and following the election, Cosby was in fact charged. ${ }^{179}$ Cosby's lawyers complained, understandably, that the case had become a "political football." "180 In Los Angeles, District Attorney Jackie Lacey was heavily pressured when running for reelection in 2016 to indict a police officer who had shot an unarmed homeless man; an attorney for the victim's family said it would be "political suicide" for Lacey not to pursue the case. ${ }^{181}$ Lacey won reelection without making a decision in the case, but she was running unopposed. ${ }^{182}$ Even the recent prosecutorial elections in Cook County, Illinois, and Cuyahoga County, Ohio-widely celebrated as victories for progressive approaches to criminal justice-raise the

179 See Abby Ohlheiser, How the Results of a Small, Dramatic County Election May Have Shaped the Charges Against Bill Cosby, WASH. PosT (Dec. 31, 2015), https://www.washingtonpost. com/news/arts-and-entertainment/wp/2015/12/31/how-the-results-of-a-small-dramatic-countyelection-may-have-shaped-the-charges-against-bill-cosby/ [https://perma.cc/39TV-VDKS].

180 Laura McCrystal \& Jeremy Roebuck, Cosby Claim: Sex Assault Charge Politically Motivated, PHILlY.COM (Jan. 1, 2016), http://www.philly.com/philly/news/20160101_Cosby_claim _CCharge_politically_motivated.html [https://perma.cc/BR7W-W5UH].

181 Marisa Gerber \& Kate Mather, D.A. Lacey Under Pressure After Beck Recommends Criminal Charges Against Officer in Fatal Shooting, L.A. TIMES (Jan. 14, 2016), http://www.latimes. com/local/lanow/la-me-ln-beck-lacey-charges-venice-20160112-story.html.

182 See Marisa Gerber, The Pressure is on for Jackie Lacey, L.A.'s First Black District Attorney, After High-Profile Police Killings, L.A. Times (Dec. 26, 2016), http://www.latimes.com/ local/lanow/la-me-jackie-lacey-police-shootings-20161226-story.html. 
disturbing prospect of district attorneys in the future fearing political punishment if they fail to indict police officers, or other potential defendants, that the public believes are guilty. That seems uncomfortably close to trial by plebiscite.

This danger-prosecution by plebiscite - is a large part of the reason that some legal scholars have long opposed the practice of electing district attorneys and have resisted the suggestion that the ballot box should serve as a tool of prosecutorial accountability. ${ }^{183}$ They may be right; we might be better off with prosecutors who were appointed. For the foreseeable future, though, the point is largely moot: the vast majority of district attorneys will be elected. The question is what kind of control the public will exercise through those elections. The recent string of elections in which prosecutors have won office by promising more thoughtful and less punitive criminal justice policies, or more meaningful oversight of the police, underscore the contingency of the politics of crime, and provide grounds for optimism that political oversight of prosecutors can operate in positive and productive ways. But it is worth keeping in mind the ways in which political oversight can be far less constructive - in particular, the risk of politicizing the treatment of particular defendants. Avoiding that prospect is one more reason to try to develop tools that will help voters to assess prosecutors based on how they run their offices day in and day out. 